Retraction

\title{
Retracted: A Bimodel Algorithm with Data-Divider to Predict Stock Index
}

\author{
Mathematical Problems in Engineering
}

Received 1 December 2020; Accepted 1 December 2020; Published 28 January 2021

Copyright $\odot 2021$ Mathematical Problems in Engineering. This is an open access article distributed under the Creative Commons Attribution License, which permits unrestricted use, distribution, and reproduction in any medium, provided the original work is properly cited.

Mathematical Problems in Engineering and the authors have retracted the article titled "A Bimodel Algorithm with DataDivider to Predict Stock Index" [1] due to errors identified in the figures and data by the authors.

The programs used were modified by the authors during the study, and it was identified that Figures 2 and 3 in the published article do not correspond with the test sets. Figures 4, 5, 8, and 9 are incorrect as a result of this error.

The authors apologized and requested the retraction of the article, which has been in agreement with the editorial board.

\section{References}

[1] Z. Wang, J. Hu, and Y. Wu, "A Bimodel Algorithm with DataDivider to Predict Stock Index," Mathematical Problems in Engineering, vol. 2018, Article ID 3967525, 14 pages, 2018. 